\title{
Edyta GŁowacka-SobIEch
}

Uniwersytet im. Adama Mickiewicza

w Poznaniu

\section{ZAPOMNIANE UCZONE UNIWERSYTETU POZNAŃSKIEGO: DOC. DR HAB. WISŁAWA KNAPOWSKA - NAUCZYCIELKA I HISTORYCZKA (7.06.1889-8.05.1956)}

\begin{abstract}
Aвstract. Głowacka-Sobiech Edyta, Zapomniane uczone Uniwersytetu Poznańskiego: doc. dr hab. Wisława Knapowska - nauczycielka i historyczka (7.06.1889-8.05.1956) [Forgotten Female Scholars of Poznań University - Prof. Wisława Knapowska - Teacher and Historian (7.06.1889-8.05.1956)]. Studia Edukacyjne nr 50, 2018, Poznań 2018, pp. 151-158. Adam Mickiewicz University Press. ISSN 1233-6688. DOI: $10.14746 /$ se. 2018.50 .10

The text introduces the figure of Wisława Knapowska, one of the first independent scholars of Poznan University, a researcher and teacher of the best schools in the interwar period. It shows her path to academic independence and the many barriers she encountered in her life. The text is part of the socalled herstory, asking for the past and history of women's narratives.
\end{abstract}

Keys words: herstory, history, didactics, interwar period, emancipation

\section{Wprowadzenie}

Okres międzywojenny to czas, kiedy pracę naukową i dydaktyczną na polskich uczelniach podejmowała (przy oporze części środowiska naukowego mężczyzn i opinii publicznej) pierwsza generacja absolwentek studiów wyższych ${ }^{1}$. Biografie tych uczonych zawierały zazwyczaj liczne studia zagraniczne na najlepszych europejskich uniwersytetach, jako że na ziemiach polskich kobiety miały możliwość studiowania dopiero od 1897 roku na Uni-

${ }^{1}$ E. Mania, Kobiety w powojennej historii Uniwersytetu Poznańskiego, Kronika Miasta Poznania. Poznanianki, 2011, 1, s. 240-241. 
wersytecie Jagiellońskim w Krakowie i Uniwersytecie Jana Kazimierza we Lwowie, a od 1915 roku - na Uniwersytecie Warszawskim².

Stopień doktora, częstokroć z licznymi obwarowaniami dotyczącymi wykonywania zawodu, uzyskiwała systematycznie rosnąca liczba kobiet, jednak habilitacja była wciąż postrzegana jako wyjątkowe osiągnięcie, stąd status samodzielnego pracownika miały bardzo nieliczne uczone. W biografiach pierwszych naukowczyń pracujących i współtworzących Uniwersytet Poznański znajdziemy wiele wspólnych wątków, wynikających ze zmian społeczno-kulturowych na przełomie XIX i XX wieku, związanych z walką o prawa kobiet.

Dlaczego wiemy o nich tak niewiele?

Mimo że obecność kobiet w nauce nie jest już kwestionowana, to wciąż odczuwamy konsekwencje wielowiekowej dyskryminacji kobiet w tej sferze. Kobiety, stanowiące połowę społeczeństwa, będące podmiotami tworzącymi dzieje ludzkości, zostały z nich „wypchnięte” i wymazane, jako „niegodne historii”, a pamięć o niezwykłych kobietach, również tych tworzących naukę, nadal zajmuje dziejowe "boczne tory”, ,zakamarki” i „marginesy". Tym samym, kolejnym pokoleniom kobiet odebrane jest prawo do poznania losów matek, babek, prababek..., dorobku wybitnych naukowczyń, artystek, działaczek, nauczycielek, a zatem prawo do identyfikacji, korzystania z symbolicznego kapitału przodkiń i wsparcia w odważnym szukaniu własnej drogi.

Mam nadzieję, że zrealizowane przeze mnie badania historyczne zaowocują nie tylko interesującymi odkryciami, studium naukowych karier i biografii bez wątpienia nieszablonowych postaci kobiet współtworzących Uniwersytet Poznański, ale także staną się impulsem do refleksji, jak również dalszych badań dla historyków, pedagogów, autorów materiałów edukacyjnych, nauczycieli historii i innych dziedzin humanistycznych oraz osób wrażliwych na problematykę budowania społeczeństwa obywatelskiego, rozwój demokracji, a także kwestie równouprawnienia kobiet i mężczyzn w nauce oraz społeczeństwie. Ufam, że biografie badaczek sprzed stu lat mogą stać się inspiracją dla młodych pokoleń studentek i naukowczyń, potwierdzeniem, że uniwersytet jest przestrzenią, którą mogą współtworzyć na równych prawach i we wszystkich dziedzinach naukowych.

2 B. Czajecka, "Z domu w szeroki świat". Droga kobiet do niezależności w zaborze austriackim w latach 1890-1914, Kraków 1990; J. Kolbuszewska, Kobiety w akademii. Droga do samodzielności naukowej polskich historyczek w XX stuleciu, [w:] Kobiety niepokorne. Reformatorki - buntowniczki rewolucjonistki. Herstorie, red. I. Desperak, I. Kuźma, Łódź 2017, s. 93-108; E. Tylińska, Drogi do kariery akademickiej kobiet na ziemiach polskich na przełomie XIX i XX wieku, Kwartalnik Historii Nauki i Techniki, 2003, 3-4, s. 155-162. 


\section{Wisława Knapowska - biografia}

Do grona zapomnianych naukowczyń Uniwersytetu Poznańskiego należy zaliczyć postać Wisławy Knapowskiej, historyczki, pedagożki i nauczycielki, związanej całe życie z Poznaniem³.

Urodziła się 7 czerwca 1889 roku w stolicy Wielkopolski, w rodzinie Stanisława, właściciela drukarni oraz wydawcy dziennika „Postęp” i Marii z Rzarzyńskich4. Jej bratem był Roch Knapowski (1892-1971), ekonomista, historyk i przyszły profesor prawa Uniwersytetu Poznańskiego. Oprócz niego miała jeszcze trzy siostry: Zofię, Kazimierę i Anielę (wszystkie były urzędniczkami państwowymi).

Swoją edukację Wisława Knapowska rozpoczęła w szkole żeńskiej Antoniny Estkowskiej, a następnie kontynuowała ją w Wyższej Szkole im. Ludwiki. Była także absolwentką Seminarium Nauczycielskiego, związanego z tą ostatnią placówką ${ }^{5}$. Knapowska ukończyła je w 1909 roku, co dało jej uprawnienia oraz możliwość nauczania $\mathrm{w}$ szkole średniej. Pierwszą pracę $\mathrm{w}$ charakterze nauczycielki podjęła już w 1909 roku, w prywatnej szkole żeńskiej Anastazji Warnkówny w Poznaniu, jako że wcześnie straciła oboje rodziców (zmarli w marcu 1905 roku) i zmusiła ją do tego sytuacja materialna.

Porzuciła tę posadę jednak w 1914 roku, kiedy placówka przeszła pod niemiecki zarząd. Do 1917 roku pracowała jako nauczycielka prywatna, udzielając korepetycji.

W 1918 roku w Zakładzie Ludwiki złożyła egzamin dojrzałości. Podczas I wojny światowej nadal udzielała lekcji prywatnych oraz prowadziła tajne kursy nauczania, które firmowane były przez kobiece stowarzyszenie „Warta", gdzie ${ }^{6}$ :

celem Towarzystwa (...) jest udzielanie opieki dzieciom takowej potrzebującym, a środkiem najważniejszym do dopięcia jego zachęta wzajemna do prywatnego ucze-

${ }^{3}$ H. Zubalowa, Knapowska Wistawa, [w:] Polski stownik biograficzny, t. XIII, Wrocław - Warszawa - Kraków 1967-1968, s. 108-109; Knapowska Wistawa, [w:] Stownik historyków polskich, Warszawa 1994, s. 231-232; Spuścizna W. Knapowskiej, Archiwum PAN, Oddział w Poznaniu, sygn. P-III-2; Wistawa Knapowska, Archiwum UAM, sygn. 82/186.

${ }^{4}$ Stanisław Knapowski, mieszkaniec Poznania i patriota lokalny. Pod koniec XIX wieku był jednym z aktywniejszych bojowników demokracji polskiej w Poznaniu, o zabarwieniu dość radykalnym, jak na ówczesne czasy. Idee swe szerzył właśnie za pomocą dziennika „Postęp", którego był wydawcą i głównym redaktorem. Brał żywy udział w pracach i akcjach społecznych.

${ }^{5}$ Mimo iż była absolwentką i nauczycielką tej szkoły, została pominięta w oficjalnych publikacjach związanych z istnieniem tej placówki. Pracowała tam także jako nauczycielka, między innymi innej badaczki Uniwersytetu Poznańskiego - Rufiny Ludwiczak (matura rocznik 1925). Uczyła ją języka francuskiego. Patrz: Zjazd Dąbrowczański. Listopad 2005. 175 rocznica istnienia szkoły, Poznań 2005.

${ }^{6}$ https://kolektywbibianny.wordpress.com/2012/10/02/towarzystwo-warta/[30.08.2018]. 
nia dzieci w granicach przez prawo dozwolonych, urządzanie zabaw i majówek dla dzieci, popieranie kolonii feryjnych itp. ${ }^{7}$

W rzeczywistości „Warta” była organizacją wyłącznie kobiecą, co w tamtych czasach stanowiło fenomen, a kobiety skupione wokół Towarzystwa narażały się każdego dnia, zajmując się przede wszystkim tajnym nauczaniem dzieci języka polskiego ${ }^{8}$.

W roku 1918/1919 rozpoczęła studia w Monachium. Wybrane przez Knapowską kierunki to: historia, historia sztuki oraz filologia romańska. Powróciła do Poznania, kiedy tutaj w 1919 roku rozpoczął swoją działalność Uniwersytet Poznański (wówczas Wszechnica Piastowska) ${ }^{9}$. W arkana sztuki w dziedzinie historii nowożytnej wprowadzali ją Kazimierz Tymieniecki i Adam Skałkowski - uczyła się zatem u najlepszych. Studiowała ponadto romanistykę i germanistykę. W 1921 roku Knapowska złożyła państwowy egzamin dla kandydatów na nauczycieli szkół średnich (otrzymała oceny celujące i bardzo dobre) z historii (przedmiot główny) oraz języków, niemieckiego (przedmiot poboczny) i francuskiego (przedmiot główny). Knapowska była poliglotką, te dwa języki znała świetnie, ale posługiwała się biegle także angielskim, włoskim i rosyjskim.

Tytuł doktora uzyskała, „po odbytych rigorosach”, 17 lutego 1923 roku na podstawie pracy zatytułowanej „Wielkie Księstwo Poznańskie przed wojną krymską". Swoje badania oparła w niej na nieznanych dotąd źródłach pruskich. Wysoki poziom dysertacji oraz talent dydaktyczny spowodowały, że Knapowska związała się w Uniwersytetem Poznańskim już w charakterze nie studentki, ale wykładowczyni i badaczki. Prowadziła bowiem od 1925 roku wykłady zlecone z dydaktyki historii, a od 1931 roku pełniła, na zlecenie Ministerstwa Wyznań Religijnych i Oświecenia Publicznego, funkcję kierowniczki ogniska metodycznego dla nauczycieli historii Okręgu Szkolnego Poznańskiego.

Cały czas była wówczas aktywna jako nauczycielka. Pracowała w poznańskich szkołach średnich przez cały okres międzywojenny, gdzie uczyła literatury oraz języka francuskiego. Najpierw w gimnazjum żeńskim im. Dąbrówki (1921-1931), a następnie w gimnazjum im. Generałowej Zamoyskiej (1931-1939). Za pracę w szkole została doceniona przyznaniem Złotego Krzyża Zasługi w 1937 roku.

Czas II wojny światowej Knapowska przeżyła w Poznaniu. Zajmowała się wówczas tajnym nauczaniem, pozbawiona całego majątku i wyrzucona

7 Tamże.

8 Tamże.

9 P. Hauser, T. Jasiński, Wstęp, [w:] Alma Mater Posnaniensis. W 80 rocznice utworzenia Uniwersytetu w Poznaniu, red. P. Hauser, T. Jasiński, J. Topolski, Poznań 1999, s. 5. 
z mieszkania, co musiało być dla niej doświadczeniem trudnym, skoro nieomal w każdej powojennej ankiecie personalnej mocno to podkreślała.

Do legalnego wykonywania swojego zawodu nauczycielki i naukowczyni powróciła po 1945 roku w tych samych co wcześniej placówkach (gimnazja oraz uniwersytet).

W 1945 roku habilitowała się w Uniwersytecie Poznańskim i została powołana na docenta etatowego na uczelni. Senat uczelni zatwierdził jej habilitację 21 grudnia tego samego roku. Rektorem UP był wówczas prof. Stanisław Dąbrowski. Rozprawa habilitacyjna nosiła tytuł: „Nawroty polskich ruchów zbrojnych 1830-1834. Z dziejów dyplomatycznych i rewolucyjnych Wolnego Miasta Krakowa " (Poznań 1948), która pomyślana była jako część monografii o dziejach Wolnego Miasta Krakowa. Jest to jednocześnie najobszerniejsza praca Knapowskiej.

Mianowanie na etatowego docenta UP spowodowało, że Knapowska musiała zrezygnować (de facto została zwolniona) z pracy w szkolnictwie średnim. Było to o tyle przykre, że w tym czasie utrzymywała nie tylko siebie, ale także ciotkę, siostrę swojej matki.

W grudniu 1954 roku Knapowska uzyskała tytuł zastępcy profesora, zaś w styczniu 1955 roku tytuł naukowy docenta, nadany uchwałą Centralnej Komisji Kwalifikacyjnej dla Pracowników Nauki. Od lutego tego roku zatrudniona była jako samodzielny pracownik nauki przy Katedrze Historii Polski.

Nieomal przez całe swoje życie była także związana z działalnością Polskiego Czerwonego Krzyża oraz Polskiego Towarzystwa Historycznego.

Wisława Knapowska zmarła niespodziewanie, aczkolwiek w źródłach archiwalnych można znaleźć informacje, że chorowała i przebywała na zwolnieniach, 8 maja 1956 roku i została pochowana na cmentarzu jeżyckim w Poznaniu. Jej siostra Kazimiera zajęła się pogrzebem. Sama Wisława nigdy nie założyła rodziny i miała dystans do tej sytuacji. W 1951 roku, w ankiecie personalnej napisała bowiem w rubryce "stan majątkowy rodziców męża/ żony”: „męża nie mam i nie miałam, więc rodzice męża nie istnieją!" 10

\section{Wisława Knapowska - zainteresowania badawcze i osiągnięcia naukowe}

Zainteresowania Wisławy Knapowskiej oscylowały wokół tematów: dydaktyki historii oraz dziejów ziem polskich w XIX wieku, ze szczególną uwagą nakierowaną na Wielkopolskę, okres Wiosny Ludów oraz polską polistopadową emigrację. Opublikowała w tym zakresie szereg prac: „Z zagadnień

${ }^{10}$ Wistawa Knapowska, Archiwum UAM, sygn. 82/186. 
metodyki nauczania historii” (1926 r.), ,"Rozwój dydaktyki historii u nas i za granicą" (1928 r.), „Kandydaci do tronu polskiego w czasie wojny krymskiej” (1927 r.), „Dzieje fundacji ks. Ludwiki Radziwiłłowej” (1930 r.). Ta ostatnia praca przyczyniła się do zainteresowania środowiska przeszłością poznańskiego szkolnictwa.

Swoje prace, w tym liczne studia i artykuły, publikowane w zacnych i prestiżowych czasopismach, Knapowska opierała na słabo dotąd wykorzystywanych i poznanych źródłach, które odnajdowała i analizowała wnikliwie w Raperswilu, Paryżu, Londynie, Berlinie, Rzymie, Wiedniu. W prowadzonych badaniach przydało się z pewnością jej doskonałe opanowanie języków. Swoje talenty poliglotki prezentowała także poprzez udział w licznych zagranicznych kongresach i konferencjach, prowadzonych w językach kongresowych. Wówczas zazwyczaj posługiwała się językiem francuskim: „La France, la Prusse et la question polonaise en 1848” (Oslo 1928 r.). „La politique de Metternich avant l'annexion de la république de Cracovie" (Varsovie 1933).

Po II wojnie światowej zainteresowania Wisławy Knapowskiej oscylowały wokół tematu jej pracy habilitacyjnej, czyli okresu I połowy XIX wie$\mathrm{ku}$, ze szczególnym uwzględnieniem tematyki związanej z Wiosną Ludów w Wielkim Księstwie Poznańskim. Wówczas to, w 100-lecie tej europejskiej rewolucji opublikowała dwa teksty w "Przeglądzie Zachodnim”, „Z problematyki dziejów roku 1848 w Poznańskim” oraz „Europa o rewolucji 1848”. Przed śmiercią zajęła się ponadto historią organizacji Lud Polski - Gromada rewolucyjna Londyn („Kwartalnik Historyczny” 1955) oraz Ksawerym Liske i jego opiniami na temat środowiska naukowego Poznańskiego Towarzystwa Przyjaciół Nauk („Roczniki Historyczne” 1957, R. 23 - publikacja pośmiertna).

Ponadto, Knapowska zajmowała się edycją źródeł do nauki historii Polski, z Wielkopolską w tle, oraz pozostawiła kilka rękopisów, zdeponowanych obecnie w Archiwum Polskiej Akademii Nauk w Poznaniu ${ }^{11}$.

\section{Zakończenie}

Wisława Knapowska była ceniona za swoją rzetelność warsztatową oraz sumienną pracę. Jej styl pisarski jest precyzyjny i dość oszczędny. Autorka ważyła każde słowo i była dość wstrzemięźliwa w ozdobniki. Jej opracowania nie są zbyt obszerne, często mają charakter przyczynkarski i polemiczny. Takie prace historyczne dobrze się czyta. Niemniej jednak trudno znaleźć odwołania do jej prac w opracowaniach innych historyków oraz jej nazwisko na liście obowiązkowych lektur dla studentów historii, nawet w Poznaniu,

11 H. Zubalowa, Knapowska Wistawa, s. 108-109. 
mimo że niemal całość jej dorobku jest dostępna w Bibliotece Uniwersyteckiej UAM.

W zakresie pokonywania barier mentalnych i społecznych stereotypów Wisława Knapowska jest postacią wręcz przykładową: zapracowana, sumienna, obarczona licznymi obowiązkami zawodowymi i pozbawiona życia rodzinnego. Ale jak zaznaczyła Dorota Mazurczak,

Kariery akademickie kobiet (tzn. osiągnięcie statusu samodzielnego pracownika naukowego) nie były w okresie międzywojennym zjawiskiem powszechnym. Zauważyć przy tym należy, że Uniwersytet Poznański, być może jako uczelnia nowa, nie stawiał barier ani przed studentkami, ani przed kobietami przy zatrudnianiu czy uzyskiwaniu kolejnych stopni (...). Stosunkowo skromna liczebnie reprezentacja kobiet w społeczności uniwersyteckiej jest więc odbiciem zjawiska szerszego - bardzo powolnego, stopniowego osiągania równouprawnienia kobiet w różnych dziedzinach życia społecznego w dwudziestoleciu międzywojennym ${ }^{12}$.

Wisławie Knapowskiej należy zatem przypisać pionierstwo i przecieranie szlaków polskim/poznańskim historyczkom.

\section{BIBLIOGRAFIA}

\section{Źródła archiwalne}

Spuścizna W. Knapowskiej, Archiwum PAN, Oddział w Poznaniu, sygn. P-III-2.

Wisława Knapowska, Archiwum UAM, sygn. 82/186.

\section{Źródła drukowane}

Poczet członków Poznańskiego Towarzystwa Przyjaciót Nauk 1857-2007. Źródła do Dziejów Poznańskiego Towarzystwa Przyjaciół Nauk, pod red. A. Pihan-Kijasowej, Poznań 2008. Uniwersytet Poznański w pierwszych latach swego istnienia (1919, 1919-20, 1920-21, 1921-22, 1922-23): za rektoratu Heljodora Święcickiego. Księga pamiątkowa, red. A. Wrzosek, Poznań 1924.

\section{Słowniki}

Knapowska Wistawa, [w:] Stownik historyków polskich, Warszawa 1994.

Zubalowa H., Knapowska Wistawa, [w:] Polski stownik biograficzny, t. XIII, Wrocław - Warszawa - Kraków 1967-1968.

\section{Opracowania}

Alma Mater Posnaniensis. W 80 rocznice utworzenia Uniwersytetu w Poznaniu, red. P. Hauser, T. Jasiński, J. Topolski, Poznań 1999.

Czajecka B., "Z domu w szeroki świat”. Droga kobiet do niezależności w zaborze austriackim w latach 1890-1914, Kraków 1990.

Dzieje Uniwersytetu im. Adama Mickiewicza: 1919-1969, red. Z. Grot, Poznań 1972.

12 D. Mazurczak, Kobiety na Uniwersytecie Poznańskim w okresie międzywojennym, [w:] Alma Mater Posnaniensis, s. 166. 
Jakś-Ivanovska M., Profesorowie Uniwersytetu Poznańskiego 1919-1939. Portret demograficzno-społeczny, Roczniki Dziejów Społecznych i Gospodarczych, 2016, LXXVI.

Klanowski T., Uniwersytet im. Adama Mickiewicza w Poznaniu 1945-1964, Poznań 1965.

Kolbuszewska J., Kobiety w akademii. Droga do samodzielności naukowej polskich historyczek $w$ XX stuleciu, [w:] Kobiety niepokorne. Reformatorki - buntowniczki - rewolucjonistki. Herstorie, red. I. Desperak, I. Kuźma, Łódź 2017.

Labuda G., Uniwersytet Poznański w latach 1919-1969, Poznań 1969.

Mania E., Kobiety w powojennej historii Uniwersytetu Poznańskiego, Kronika Miasta Poznania. Poznanianki, 2011, 1.

Mazurczak D., Kariery akademickie kobiet w Polsce międzywojennej - Uniwersytet Poznański, [w:] Kobieta i kultura: kobiety wśród twórców kultury intelektualnej i artystycznej w dobie rozbiorów i w niepodległym państwie polskim: zbiór studiów, red. A. Żarnowska, A. Szwarc, Warszawa 1996.

Miśkiewicz B., Uniwersytet im. Adama Mickiewicza 1919-1989, Poznań 1989.

Miśkiewicz B., Uniwersytet Poznański: przeszłość, teraźniejszość, przyszłość, Poznań 1972.

Nauka w Wielkopolsce. Przeszłość i teraźniejszość. Studia i materiały, red. G. Labuda, Poznań 1973.

Tylińska E., Drogi do kariery akademickiej kobiet na ziemiach polskich na przełomie XIX i XX wieku, Kwartalnik Historii Nauki i Techniki, 2003, 3-4.

Zjazd Dąbrowczański. Listopad 2005. 175 rocznica istnienia szkoły, Poznań 2005.

\section{Źródła internetowe}

https:/ / kolektywbibianny.wordpress.com/2012/10/02/towarzystwo-warta/[30.08.2018]. 